\title{
Diction in Arab and Indonesian Proverb: a Comparative Study
}

\author{
Yani'ah Wardani \\ Arabic Language and Literature Department \\ Syarif Hidayatullah State Islamic University Jakarta, Indonesia \\ yaniah.wardani@uinjkt.ac.id
}

\begin{abstract}
This writing aim to know the characteristic of diction in two Arab and Indonesian proverb, also the extrinsic element that affected it, include the differentiation and equation between it. There are differentiations in the appearance of diction either in Arab or Indonesia. In Arab proverb, it must be a story or legend to explain the reason beyond the diction. As the opposite, it is does not have to be story or legend beyond the appearance of Indonesian proverb. However, both proverbs have same mission, called a harmony. This research used a literature review with two literature theory, Kathleen Morner\&Ralph Rausch, NTC,S Dictionary of Literary Terms, 1998 and Ali Abu al- Khasyab, n.d.This research's result proved that each proverb, Arab and Indonesian, has their own characteristic that caused by the extrinsic unsure that affected it. For example like the used of animal names, universe phenomena, culture, plant and other. Moreover, there are dominant extrinsic unsure in each proverb as the influence from the geographical differentiation between it. The contribution of this writing, gives the lesson about the beauty of language in the shape of good advice for the observer of literature critical, in the study of diction's comparative.
\end{abstract}

Keywords - Comparative Literary, Arab and Indonesian Proverb

\section{INTRODUCTION}

The diction used in the proverb as an intrinsic element can not stand alone without other elements influencing it, such as geography, nature, culture and tradition. Thus, diction as an intrinsic element of literary works is strongly influenced by extrinsic elements. As an example, the Arabic proverb states "qabla ar rimā tumlau al kanāin" (fill the bow before the archery).

In the Indonesian proverb, the amsâl matches as "Have an umbrella ready before the rain". Intrinsically, the two proverbs have the same massage that everything must be well prepared. Extrinsically, however, the two proverbs are influenced by two different elements, namely the diction used in amtsâl is strongly influenced by the tradition of fighting "bow", while at the level of the Indonesian proverb, the geographical element is very dominant in influencing the style of the language such as the word "rain" is identical to tropical country. Based on this, it appears that the difference in the emergence of diction in the proverb in accordance with conditions that affect it, although the messages contained in it the same.

There is an example of famous Indonesian proverb i.e
"Alike as two peas in a pod" commensurate with amsial "wāfaqa Syannun Tabaqata" which means showing the harmony of the couple in an arranged marriage. Thus, in these two proverbs there is an element of difference in the appearance of the proverb. The Indonesian proverb simply appears, whereas amtsal is based on historical causes that occur in society [1, p. 84].

This study will explain the characteristics of diction in the two Arabic and Indonesian proverbs, how is the dictionability in each proverb and whether there is an Indonesian proverb influenced by the Arab proverb.

\section{METHOD}

This writing used comparative method to understand the literature study from the intrinsic and extrinsic point of view. In addition, intrinsic is a word that selected from that proverb (diction). Mean while, extrinsic is focused on the things that influence the word, for instance environment and geography factor. Ali Abu al Khasyab in Turatsuna al Adaby [1], stated that Amtsal devided into two; iftirody (absolute) and khurafy(myth). Iftirody is a proverb that based on history, and khurofy based on myth. These statement is also emphasized by the opinion of Kathleen Morner \& Raplh Rausch [2] that stated comparative literature examine the influence of styles, source, theme and the species among different literature. Comparative literature also examines the relation between myth, legend, and epic, also the development of shape and literature ${ }^{e c}$ genre [3].

\section{RESULTS ANDDISCUSSION}

Diction is used as a symbol in the proverb, influenced by extrinsic factors that develop in society, such as belief, morality, culture, politics, etc. Based on the results of research on a number of amsial, it is known that the diction used and developed in the Arab society is a parable symbol of human names, animal names, heavenly bodies, sun, moon, stars, earth, natural phenomena such as wind, clouds, and plant. It is found in the al-Munjid dictionary [4, p. 1013] .As a result, the symbol of a wise man: Ahkam min Luqmān al Hakìm (Wiser than Lukman al-Hakim), symbol of generous humanity [4, pp. 982-1000]. The symbol of ugly humans, among others stingy man, for example, the symbol of human breaking promises Mawā' '̄du 'Urkūb (Urkub's promises) [5, p. 120]. This is called al-amíāl al-târikhiyyah, an amsial that emerges from 
the history of the ruler or the ruler of a people. That aforementioned is different from the writer's observation of the proverbial tradition of Indonesia, which is not found the name of the person who used as a symbol in the proverb in Indonesia. Nevertheless, there are some proverbs that use the word "man" or "people" in general, without a specific name, such as: putting charcoal upfront people, that is a parable for people who are very anxious because they get embarrassed.

The camels in Arabic proverbs occupy the second position after birds. However, the mentioned birds come from various species, so the camels still dominate the category of animals enshrined in Arabic proverbs. Counting more than 16 words of camels are recorded in Arabic proverbs, namely: ibil, ba'îr, Umm Qasy'am, hîm, jamal, huwâr, and nâqah [4, p. 980] in line with the Indonesian proverb "shallow water has ripples","Hattā yalija al jamalu fì sammi al Khayāt" (Until the camel enters the needle) [6, p. 365] the equivalent of the Indonesian proverb, "Like an owl craving for the moon", expecting something impossible to do [7]. In addition, for an amtsal that uses dog diction [6, p. 146]. Amsial that uses the word dog, as an allusion to something common to humans: la talidu al dzi'batun illa dzi'ban (The forest dog will give birth to a jungle dog), an allusion to someone who has a character or has a character similar with their parents. Similar in the Indonesian proverb "the fruit falls not far from the tree". This proverb with a pattern like this in Arabic literature is called alamisal al-sâ'irah, that is changing a custom, custom, behavior or glory of a nation whether rural or urban life. The horse dictions are used as symbols, such as: al-faras, al-shi'âb, bulayyaq, al- jawâd, and al-mahr.[5, p. 604]. Diction of bird placed at the main position in Arabic proverbs: pigeon, eagle, crow, sparrow, hamara, owl, ostrich, anuq, shafir, qirilla, peacock, Abu baraqisy, labad, qatha, thawus, peacock, labad and qatha. However, among the birds there are three types of birds that often mentioned, namely: hawks, crows, and ostriches. There are several names that are used for eagles, namely: shaqar, 'uqab, nasar, and al-bazi. Nasr is the most powerful bird, has very sharp, strongest, highest-flying eyes, and is feared by other birds. There are several nicknames for this bird, namely: Abu al-Abrad, Abu al-Ashba ', Abu Malik, Abu al-Minhal, and Abu Yahya. In the traditions of ancient Arab society, crows are regarded as a symbol of misfortune and death. Lion's Diction among Arabians as a symbol of valor and courage. The lion statue called "Yagus" even became one of the Arab Jahiliyah's gods. [8]. Amśal who uses lions and the like as figures, for example:"ajrau min laitsi Yakhoffān" (More courageous than the Yakhaffan lion) [6, p. 105]. "Yakhaffan" is a very famous lion's name of courage. This is called al-amtsal al-fardhiyyah, which is a proverb attributed to animals [9].

Beside the dictions of humans and animals, there are also dictions caused by traditions and culture. Philip K. Hitti in his book [10], states that in earlier Arabic times was known as Ayyâm al-Arab. According to him, Ayyâm al-Arab is an arena of tribal struggle to be one of the religious social institutions in their lives such as the Basus war, Dâhis wa al-Ghubarâ '. In the amtsal, there are several dictions that are related to the
Arab war tradition, namely the tools of war such as arrows, bows, spears, and swords, prisoners, and spoils. The tool used in the tradition of war is the "sword","Sabaqa al saifu al 'adzala" The sword has preceded the scolding, in tune with the Indonesian proverb "Rice has become porridge" is the parable of something that has already happened. Here there is a distinction between tradition and culture between the two countries in terms of the use of the diction that lies behind it, the sword which is an Arabian tradition, while the rice (porridge) is an Indonesian food tradition.

The sun, moon, and stars are celestial bodies that are regarded as sources of light and heat that affect the power of human, animal and plant life. Dictionary stars appear repeatedly with different names, such as, "ab'ad min manat atsurayy $\vec{a}$ " (Further than a tsuraya star), the proverb is to declare something that is hard to achieve. Other names of star names appearing in the amsal diction, namely Ayyuq, Suhail. Proverbs using the diction of the Sun:" likulli syamsin maghrab" (Every sun has its setting), as an allegory that glory, power, splendor and others there must be an ending period. In this case, it is clear that the sun is symbolized as power, glory, greatness, as well as the moon, e.g "ahsanu min asy Syamsi wa al Qamar" ( More glorious than the sun and moon). This proverb declares something extraordinarily beautiful or beautiful. The Earth's Diction, though not used as a symbol of belief by Arab society, is seen in their proverb"bi al ardhi waladatka ummuka" (On earth you were born by your mother). Spoken to a proud man [6, p. 357]. Other natural phenomena that arise in amsal, is a diction about water, rain, lightning, clouds, flood, land, mirage, fire, spring, summer, rock, mountain, dust, sand, and wind. There are three types of winds mentioned in Arabic proverbs, namely rîh, haif, and nasîm [11]. The diction of plants such as dates, grapes, barwaqah, 'alqam and hanzhal, including the tree most widely mentioned in amsal. Diction of dates include the Arabic proverb often called, using the word tamr for example,"mā kullu saudā Tamrah" (Not all that black is palm), the figured to declare a person or something even if there is equality, but not all equally good. The other diction about fruit e.g wine, for example:"innaka lāa tajn̄̄ min al Syauki al "Inaba" (You will not reap wine from thorns). The point is that the ugly deeds will bring disaster and can not possibly bring goodness. The same intention is illustrated by someone who associates with a bad-tempered friend, it is unlikely that he can gain good things from him [6, p. 356].

The extrinsic element which is the characteristics of diction in the Indonesian proverb is classified into two parts,i.e elements of an agrarian nature and elements of a maritime so that cultural elements appear. Diction in Indonesian proverbs, whether related to agricultural matters as well as marine, natural aspects, flora, fauna, culture and verbs associated with both such as from natural phenomena; water, rain, and sea are elements of nature that can not be separated. In Dictionary of Indonesian proverbs, it contains more than 43 water-themed proverbs being a symbol of various human characters[12, p. 3]. The diction contains word of the sea such as: Acid in salt mountains in the sea meet in one pot of the 
proverb means men and women if a mate would meet. The diction contains mountain for example,the mountain chased will not run, missing fog it will appears which means do not rush in doing something that definitely will be achieved. The diction contains word of wind in Indonesian proverb is more used as an allegory about something that is unclear, uncertain, and futile, whether related to information, how to behave, problems, and other examples: Rumors. Wind can not be caught, smoke can not be grasped, meaning secret can not be hidden. Fire Diction, for example Fire is like a fog, this figure is used with the character of some one who is easily provoked by emotion, or irritability. The heavenly bodies are the sun, the moon, the earth and the stars. Example, Like the moon fenced with stars, Like the back of longing for the moon, As against the sun. Among the proverbs that use the word earth are: Like the earth and the sky, Where the earth is rested, where the sky is held up [12, p. 8].

Animal Diction, composed of farm animals, pets, wild animals, and aquatic animals. Such pets can be found in Indonesian proverbs: chickens, buffalo, goats and ducks, oxen, horses, and sheep. In addition to chickens, buffaloes and oxen also include farm animals attached to the life of farmers, among the proverbs that use the word buffalo: Like buffalo nose, Like frogs want to be oxen. There are three types of pets that are used as a metaphor in the Indonesian proverb, namely dogs, cats and horses. Dogs and cats are even collected and immortalized in one proverb: Like a dog with a cat. Almost all the Indonesian proverbs that use the word dog, are a bad allusion to human nature and character, for example: Dogs barking on the ass of the elephant, the parable for the humble and weak against the big and strong will not work. Cats diction, habits like meowing, stealing fish, and fear when brought a stick, made as a metaphor of human attitudes and behavior, for example Even if the cat pilgrims, back mewowing too, the parable of a wanderer, not lost even when he returned to his home town. Horse Diction is usually used as a ride or transport in urban areas in the past. This is seen in the following proverb: As a horse escapes seclusion, describes a person free of confinement [13]. As for the diction of wild animals, such as the Elephant for example, the Elephant in the eyelid is not visible, the germ on the other side of the ocean looks. This proverb means something other people's faults, even small ones remain visible, but the mistakes them selves are not realized. Dictionary Tiger in Indonesian proverb is more widely used as a symbol of strength, greatness and greatness. As for Water animals, such as fish, shrimp, crocodiles, tadpoles, eels, and frogs. More than 16 Indonesian proverbs use fish as objects, for example: Another field of locusts another of the other fish, implies that each region has different customs and rules. Another aquatic animal is a reptile-like Crocodile and belongs to a carnivore. Among the proverbs that use the word crocodile: Huge tadpole in a puddle, a huge crocodile in the ocean, meaning that everyone is in charge of his or her own territory or everyone has expertise in his field. Diction of rice, fungi, yam, taro, and durian are the names of the inner plants contained in the Indonesian proverb. Rice, like dates in Arabic proverbs, is the most widely used dictionary as a metaphor in the Indonesian proverb, as an agrarian country whose majority of the population is farmers, for example: As rice becomes increasingly dense, i.e figurative for highly knowledge able but humble people and not arrogant. Other plants that are included in the Indonesian proverb, such as reeds, betel, parasite, flowers, cucumbers, and durian. The diction of water, fish, rain, chicken, rice, each other has a strong correlation and is related to the geographical conditions of Indonesia, as tropical, agrarian and maritime regions. It is also closely related to the majority profession of Indonesian people as farmers and fishermen.

In general, when viewed from the diction that appears in the proverb, either in Arab or in Indonesia there are differences and similarities, but may be similar in massage, but not the same in the use of diction used. Perspiration occurs when the amsial Hikmiyah (advice) which is often cited by speakers in Indonesia, especially among religious leaders in delivering his lectures.

\section{CONCLUSIONS}

These similarities and differences appear on the level of diction and meaning. First, amtsal uses many people's names as a figure of speech, where as in the Indonesian proverb is not used. Second, the diction of the animals and equally used in both proverbs according to their own peculiarities. Camels and ostriches are animals that are characteristic of amtsal, while chickens and fish become special characters of Indonesian proverbs. Similarly, plant diction, amtsal is dominated by the word palm (tamr), while rice is characteristic of Indonesian proverb. This difference is more due to different geographic conditions between one country to another. Third, in the natural phenomenon, the use of the diction of celestial bodies greatly dominates amtsal, this is closely related to the belief system of the Arab community at the time, but the Indonesian proverb is more dominated by agrarian and maritime elements such as water, rain and sea. Fourth, the cultural elements used in the diction of each proverb are different from each other. Differences in the selection of words or diction this happens because influenced by extrinsic elements that exist in the surrounding, such as history, nature, geography, and culture are also different from one another.

As a scientific justification, this article has some benefits, first: Give some input to other people about the beauty of proverb understanding. Second: proverb is a part from language $e^{\text {ee }}$ style, so that people can understand more about the proverb. Third: As input for comparative literature ${ }^{e e} s$ observer. These benefits can stand as contributions in literature study.

\section{REFERENCES}

[1] I. A. abu al-Khasyab and M. abdul M. al Khoffajy, Turātsunā al Adaby,suwarun min rawāi'ihi wa malāmihihi. Mishra: Dar at Thiba'ah al Muhammadiyah.

[2] K. Morner and Ralph, "NTC's Dictionary of Literary Terms." NTC, United states of America, 1998.

[3] S. J. Husin, Pengantar Kesusastraan Bandingan. Kuala Lumpur: 
Percetakan Dewan bahasa dan Pustaka, 1994.

[4] L. Ma'luf, "al-Munjid fi al-Lughah wa al-'Alam: Fara'id al-Adab fi al-Amśal wa al-Aqwal al-Sa'irah 'inda al-Arab." Dar al-Masyriq, Beirut, 2002.

[5] Askar, "Kamus Arab-Indonesia al Azhar." Senayan Publishing, Jakarta, 2011.

[6] M. A. Rathomy, Peribahasa Bahasa Arab, 1st ed. Bandung: Alma'arif, 1982.

[7] Tim Penyusun, Kamus Besar Bahasa Indonesia. Jakarta: Balai Pustaka, 2007, p. 907.

[8] Tim Penyusun, "Ensiklopedi Tematis Dunia Islam, Akar dan Awal." Ichtiar Baru Van hoeve, Jakarta, p. 29, 2002.

[9] A. al-Iskandari and Mushtafa 'Inani, 'al-Wasith fi al-Adab al-Arabi wa Tarikhihi. Mishra: Dar al-Ma'arif, p. 18-19.

[10] Philip K. Hitti, History of The Arabs. Jakarta: Serambi, 2006, p. 110.

[11] M. Yunus, "Kamus Arab-Indonesian." PT Hidakarya Agung, Jakarta, 1990, p. 149, 489, 451.

[12] Tim penyusun, Muatan Lokal Ensiklopedi Geografi Indonesia. Jakarta: Lentera Abadi, 2006.

[13] Tim Generasi cerdas, 3.000 Peribahasa dan Pantun Paling Populer, 2nd ed. Jakarta: Generasi Cerdas, 2010, p. 264. 